\title{
The drug inventories evaluation of healthcare facilities using $A B C$ and VED analyzes
}

\author{
Faruk Yılmaz (it) \\ Department of Health Management, Faculty of Health Sciences, Istanbul University, 34147 Istanbul, Turkey
}

Cite this article as: Yilmaz F. The drug inventories evaluation of healthcare facilities using ABC and VED analyzes. Istanbul J Pharm 48 (2): 43-48.

\begin{abstract}
"Always Better Control" (ABC) and "Vital Essential Desirable" (VED) are widely used methods for controlling drug inventories. The purpose of this study is to contribute to the optimal level of drug storage for the hospital by evaluating the annual amounts spent on drugs with (ABC) and (VED). By this means, it is aimed to reduce inventory costs to an optimum level. In this study, drug consumption data of a private hospital operating in Istanbul for 2016 was used. Based on the annual unit consumption and the unit costs of 910 medicines, the total annual expenditure for each drug was calculated and drugs were ranked in increasing order according to this calculation. Drugs that accounted for $70 \%$ of the total drug expenditure were classified as Category A, 20\% were classified as Category B, and $10 \%$ were classified as Category C. The (VED) analysis was conducted with three pharmacologists and drugs were classified according to their degree of vital importance as category "Vital (V)", "Essential (E)" and "Desirable (D)". Then, the data were combined with the (ABC-VED) matrix in three separate categories. According to a $A B C$ analysis, $70.08 \%$ of this expenditure consists of 46 drugs (A), $19.88 \%$ of 92 drugs (B) and $10.04 \%$ of 772 drugs (C). According to the (VED) analysis, it has been determined that 265 drugs are in category "V", 467 drugs in "E" and 178 drugs in "D". According to the (ABC-VED) matrix, there are 298 drugs in the first category, 446 drugs in the second category and 163 drugs in the third category. Consequently, these analyzes will contribute to management especially in determining the safety stock levels of drugs that constitute a significant part of the total expenditure.
\end{abstract}

Keywords: ABC analysis, VED analysis, ABC-VED matrix, hospital, drug inventories

\section{INTRODUCTION}

Inventories are the assets with the lowest liquidity among the current assets. Therefore, compensation for investment mistakes made in stocks is time-consuming and leads to an ineffective use of resources. Thus, effective management of inventories plays an important role in preventing such cases.

Inventory management basically aims to reduce stock costs while avoiding losses caused by stock-outs and shortages. These two purposes are often conflicting. For example, keeping the inventory level high to avoid stock-outs leads to more storage space requirements, higher management costs, deterioration of products and financial loss (Gandhi and Basur 2000). In order to keep the cost of inventories low, the status of stock-outs in terms of health facilities in particular will cause negative consequences such as delay in the production of health care services, possible loss of income caused by delay, disability or death and related penal practices (Agirbas 2014)

The choice of inventory control methods that will enable the supply of the inventory to be ordered optimally without interruption varies depending on many factors such as the sector in which the business operates, the size, financial position and management mentality of the business. Hereunder, selective inventory control methods are divided into different classes according to the criteria like annual usage value, criticality, consumption rate etc. For instance; 
- $\quad$ HML (High, Medium Low) Analysis, which deals with unit price criteria,

- $\quad A B C$ Analysis, which deals with annual usage value,

- VED (Vital, Essential, Desirable) Analysis, which deals with criticality,

- $\quad$ SDE (Scarce, Difficult, Easy) Analysis, which deals with procurement difficulties,

- $\quad$ XYZ (use for 2-D study) Analysis, which deals with closing stock value of inventory at the time of physical stock verification (Madan and Ranganath 2014).

Since health institutions will be dealt with in this study, inventories should be examined both qualitatively and quantitatively. The fact that about one third of the annual hospital budget is spent on buying materials and supplies, including medicines, and the fact that services provided are directly related to human health reflect the importance of this evaluation (Kant et al. 1996). Therefore, in this study, inventories were evaluated with Always Better Control, Vital Essential Desirable and (ABC-VED) Matrix methods.

\section{ABC analysis}

$(A B C)$ analysis which is the abbreviation of "Always Better Control" statement is an important tool widely used in the identification of items that need greater attention in inventory control. (ABC) analysis is a very useful approach to material management based on Pareto's principle of "Vital few and trivial many" based on the capital investment of the item (Gupta et al. 2007). Accordingly, this analysis which is based on annual consumption of items and annual monetary volume of items is calculated by multiplying the unit price of each item with the annual consumption amount. According to $(A B C)$ analysis, about $10 \%$ of the items (A) constitute $70 \%$ of the total expenditure amount, $20 \%$ of the items (B) constitute $20 \%$ and $70 \%$ of the items (C) constitute $10 \%$ (Wandalkar et al. 2013).
In this analysis which is divided into three separate categories as $A, B$ and $C$, the items have some properties that should be considered according to their category. These properties are shown in Table 1.

The limitation of this analysis is that it is based solely on the cost of consumption and monetary value of the items. The fact that the item is not in the A category does not mean that the item is not vital. Therefore, soley using this analysis will not be adequate and appropriate (Devnani 2010).

\section{VED analysis}

(VED) analysis, consisting of the initials of 'vital, essential and desirable', divides items into three classes according to their level of significance. This analysis is usually used for the control of drugs and medical supplies and is based on the value that the items carry for human life (Tengilimoglu and Guzel 2013).

This classification which is also used in the literature as a Vital Essential and Necessary (VEN) analysis sets priorities in terms of selection, supply and use of medicines according to their health effects. Items in category $V$ are life-saving medicines that are used in treatments that should not be interrupted. Items in category E are medicines against less severe but common disease and which improve the quality of life. Items in category $\mathrm{D}$ or $\mathrm{N}$ are medicines that are used in minor complaints or self-limited illnesses and are easily found on the market (Electronic resource 1).

\section{ABC- VED matrix}

As noted above, only the use of the (ABC) method will not be adequate and appropriate. Since the items analyzed in health institutions are drugs, it is necessary to take into consideration the great importance of all drugs, even if they are not in the $A$ group. This method is implemented by creating a crosstab of two analyzes. The (ABC-VED) matrix is given in Table 2.

\section{Table 1. Properties of Group A, B and C Items}

\begin{tabular}{|c|c|c|}
\hline A items & B items & C items \\
\hline Very strict control & Moderate Control & Loose Control \\
\hline No safety stocks (or very low) & Low safety stocks & High safety stocks \\
\hline Frequent ordering or weekly deliveries & Once in three months & Bulk ordering once in six months \\
\hline Weekly control statements & Monthly control reports & Quarterly control reports \\
\hline Maximum follow-up and expediting & Periodic follow-up & $\begin{array}{l}\text { Follow-up and expediting in } \\
\text { exceptional case }\end{array}$ \\
\hline Rigorous value analysis & Moderate value analysis & Minimum value analysis \\
\hline As many sources as possible for each item & Two or more reliable sources & Two reliable sources for each item \\
\hline Accurate forecasts in materials planning & Estimates based on past date on present & Rough estimates for planning \\
\hline $\begin{array}{l}\text { Minimisation of waste, } \\
\text { obsolete and surplus (review } 15 \text { days) }\end{array}$ & Quarterly control over surplus and items & $\begin{array}{l}\text { Annual review over surplus and } \\
\text { obsolete material }\end{array}$ \\
\hline Individual posting & Small group postings & Group postings \\
\hline Central purchasing and storage & Combination purchasing & Decentralised purchasing \\
\hline Maximum efforts to reduce lead time & Moderate efforts & Minimum clerical efforts \\
\hline Must be handled by senior officers & Can be handled by middle management & Can be fully delegated \\
\hline
\end{tabular}




\section{Table 2. Always Better Control - Vital Essential Desirable Matrix}

\begin{tabular}{|lccc|}
\hline (ABC-VED) Matrix & V & E & D \\
\hline A & AV & AE & $A D$ \\
B & BV & BE & $B D$ \\
C & CV & CE & $C D$ \\
\hline
\end{tabular}

Table 3. (ABC) Analysis

\begin{tabular}{|lcccc|} 
Category & $\begin{array}{c}\text { No. of } \\
\text { drugs }\end{array}$ & $\begin{array}{c}\% \text { of } \\
\text { drugs }\end{array}$ & $\begin{array}{c}\text { Annual } \\
\text { expenditure (") }\end{array}$ & $\begin{array}{c}\% \text { of annual } \\
\text { expenditure }\end{array}$ \\
\hline A & 46 & 5.05 & 2.742 .341 & 70.08 \\
B & 92 & 10.11 & 778.190 & 19.88 \\
C & 772 & 84.84 & 392.764 & 10.04 \\
Total & 910 & 100.00 & 3.913 .295 & 100.00 \\
\hline
\end{tabular}

Table 4. Drugs Expenditure According to the Usage Areas

\begin{tabular}{|lcccc|} 
Category & $\begin{array}{c}\text { No. of } \\
\text { drugs }\end{array}$ & $\begin{array}{c}\text { \% of } \\
\text { drugs }\end{array}$ & $\begin{array}{c}\text { Annual } \\
\text { expenditure (") }\end{array}$ & $\begin{array}{c}\text { \% of annual } \\
\text { expenditure }\end{array}$ \\
\hline Chemotherapy & 70 & 7.69 & 1.578 .177 & 40.04 \\
Serum & 58 & 6.37 & 432.650 & 10.98 \\
Antibacterial & 73 & 8.02 & 389.174 & 9.87 \\
Others & 292 & 32.09 & 371.842 & 9.43 \\
Anesthetic & 11 & 1.21 & 251.245 & 6.37 \\
Contrast & 9 & 0.99 & 117.007 & 2.97 \\
Substance & & & & \\
Antithrombotic & 22 & 2.42 & 91.357 & 2.32 \\
Medications & & & & \\
Blood Product & 7 & 0.77 & 84.333 & 2.14 \\
Cardiac & 26 & 2.86 & 71.976 & 1.83 \\
Oral Feeding & 14 & 1.54 & 68.490 & 1.74 \\
\hline
\end{tabular}

The nine subcategories that are formed in the table are grouped under three main categories. These are as follows;

Category I: AV-AE-AD-BV-CV

Category II: BE-CE-BD

Category III: CD

The drugs in the first category are expensive but critical in terms of patients. These drugs need to be carefully monitored and frequently checked. Drugs in the second category are medicines with moderate importance in terms of expenditure and patients. As these drugs are used in the production of health services, and routine checks will be helpful. The drugs in the third category consist of medicines that have low importance both in terms of expenditure and patients. The drugs in this category are cheap and optional medications that do not need to be frequently checked (Yesilyurt et al. 2015).

The purpose of this study is to contribute to the optimal level of drug storage for a hospital by evaluating the annual expenses on drug with (ABC) and (VED) analyzes.

\section{MATERIALS AND METHODS}

In this study, the drug consumption data of a private hospital in Istanbul in 2016 was used and was obtained by providing the required permissions. The total annual expenditure for each drug was calculated by multiplying the annual unit consumption of 910 medicines obtained from the hospital automation system with the unit costs. Then drugs were ranked in increasing order according to their total annual expenditure. According to this alignment, drugs that accounted for $10 \%$ of the total expenditure starting from the lowest amount were classified as Category C, the next 20\% were classified as Category $B$, and the remaining $70 \%$ were classified as Category A.

In (VED) analysis, drugs were classified according to their degree of vital importance. Firstly, the drugs registered under the trade name in the hospital automation system relisted according to the active pharmaceutical ingredients. Subsequently, (VED) analysis was conducted with three pharmacologists and drugs that are of vital importance for the patient were classified as category "V", those moderately important were classified as "E" and those desirable to have in stock were classified as " $\mathrm{D}$ ".

These analyzes were then matrixed with crosstab and the drugs were included in the subgroups specifying both analysis results. These subgroups were collected in three main categories. In the matrix analysis, drugs in subcategories of (AV, $A E, A D, B V, C V)$ were included in the first category; $(B E, C E, B D)$ subcategory were included in the second category and (CD) subcategory were included in the third category.

Analysis of the data obtained from the hospital automation was made using an MS Excel program.

\section{RESULTS AND DISCUSSION}

After making the necessary arrangement to the data obtained from the hospital, the drugs were categorized according to the (ABC) Analysis, (VED) Analysis and (ABC-VED) Matrix, which are the subject of the research. The findings of this analyses are given below. Table 3 shows the results of the (ABC) Analysis, which classifies medicines by annual expenditure.

According to Table $3,5.05 \%$ (46) of the drugs were in the A group, $10.11 \%$ (92) of the drugs were in the B group and $84.84 \%$ (772) of the drugs were in the $C$ group. When examining drug expenditure percentages, drugs in group A constituted 70.08\% of the total expenditure amounting to " 3.913.295, drugs in group B constituted $19.88 \%$ and drugs in group C constituted $10.04 \%$.

Herceptin, which has the highest share in the total cost of the 910 drugs, accounts for 13\% of total drug expenditures with " 509.723 and it is classified in A category. Altuzan, Forane Likit, Erbitux, Kabiven Peripheral, Pemtrex IV, Desefin IV, Ploxal-S and so on respectively are the other medicines that constitute a significant part of total drug expenditure. The common features of these cost-effective drugs are the use of chemotherapy. In addition, cost classification was done according to the usage areas of drugs and the first 10 groups according to this classification are shown in Table 4. 
As seen in Table 4, Chemotherapy, serum and antibacterial drugs constitute an important part of the A group which consist of high cost drugs. It is especially noteworthy that chemotherapy drugs are close to nearly half of the total expenditure.

In Figure 1, the results of the (ABC) analysis are shown as a Pareto Curve developed by Vilfredo Pareto. Accordingly, the cumulative percentage of drug expenditure and cumulative percentage of drug amount are taken as a basis.

Table 5 contains (VED) analysis findings, in other words, (VEN) analysis findings. Accordingly, 265 drugs in the $V$ category (Herceptin, Altuzan, Genthaver etc.) accounted for $44.42 \%$ of the total cost, 467 drugs in the E category (Mivacron, Ondaren, Pirucin IV etc.) accounted for 47.06\%, and 178 drugs in the D category (Levmont, Oxopane, Lansor etc.) accounted for $8.52 \%$.

In Table 6, drugs were classified into 9 subcategories by an (ABC-VED) matrix, which was derived from the (ABC and VED) analysis. Then, based on this classification data, drugs were divided into 3 main categories.

The amounts and expenditure percentages of the drugs in the three main categories mentioned above are given in Table 7 . Accordingly, 298 drugs in the first main category consisting of (AV-AE-AD-BV-CV) groups (Herceptin, Altuzan, Merosid IV, Ciproktan IV etc.) constitute $82.55 \%$ of the total drug cost, 446

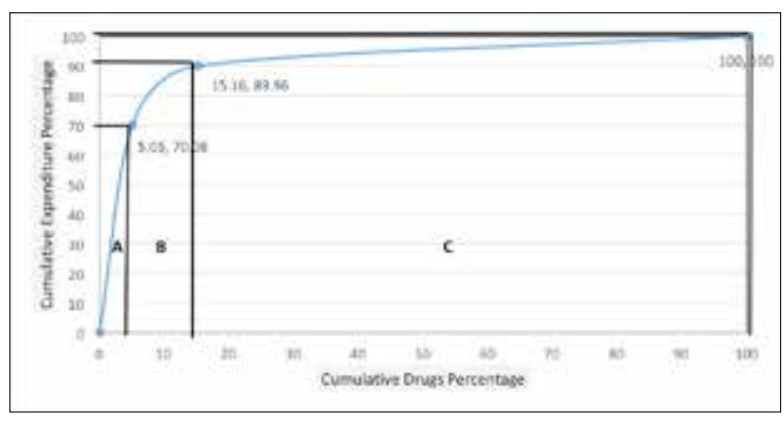

Figure 1. Cumulative Curve of (ABC) Analysis

\section{Table 5. (VED) Analysis}

\begin{tabular}{|lcccc|}
\hline Category & $\begin{array}{c}\text { No. of } \\
\text { drugs }\end{array}$ & $\begin{array}{c}\text { \% of } \\
\text { drugs }\end{array}$ & $\begin{array}{c}\text { Annual } \\
\text { expenditure (") }\end{array}$ & $\begin{array}{c}\text { \% of annual } \\
\text { expenditure }\end{array}$ \\
\hline V & 265 & 29.12 & 1.738 .351 & 44.42 \\
E & 467 & 51.32 & 1.841 .640 & 47.06 \\
D & 178 & 19.56 & 333.304 & 8.52 \\
Total & 910 & 100.00 & 3.913 .295 & 100.00 \\
\hline
\end{tabular}

drugs in the second category consisting of (BE-CE-BD) groups (Seroquel, Dikloron, Omniscan IV, Trombostat IV, Otrivine, Vastarel, Edicin IV etc.) account for $15.66 \%$ of the total drug cost and 166 drugs in the (CD) subcategory (Asist Plus, Travazol, Transamine, Stafine, Cardura XL, Deklarit, Norodol etc.) constitute $1.79 \%$ of the total cost.

In order to compare the findings of the research with other studies in the literature, the relevant data are given in Table 8. Accordingly, when $(A B C)$ Analysis data of the studies are examined, drugs percentages in $A, B$ and $C$ categories are similar to other studies (Khurana et al. 2013; Kumar et al. 2015).

According to the (VED) analysis, the percentage of vital drugs is similar to the findings of (Khurana et al. 2013) analysis, drugs percentage of essential group is similar to (Pund et al. 2016), (Vaz et al. 2008) and (Kumar et al. 2015) studies and finally, with the significant differences in the percentage of drugs called Desirable or Non-Essential, it has been observed that there is a closer value to the (Pund et al. 2016) and (Nigah et al. 2010) studies.

Finally, when we look at the (ABC-VED) matrix analysis, which is the most important classification, the findings of the study showed similar values in different headings with other study findings. Accordingly, drugs and annual expenditure in category 1 are respectively similar to the findings of the (Khurana et al. 2013) and (Pund et al. 2016), drugs and annual expenditure in category 2 are respectively similar to the research findings of (Kumar et al. 2015) and (Pund et al. 2016) and finally findings in category 3 are similar to (Nigah et al. 2010) and (Pund et al. 2016)'s. In terms of annual expenditure, it is necessary to emphasize that present study findings are almost identical that of (Pund et al. 2016)'s findings.

\section{CONCLUSION}

Health facilities must allocate resources to many assets other than drugs and medical consumables. When viewed from this aspect, the sustainability of businesses depends on distribut-

\section{Table 7. (ABC-VED) Matrix Analysis}

\begin{tabular}{|lcccc|} 
Category & $\begin{array}{c}\text { No. of } \\
\text { drugs }\end{array}$ & $\begin{array}{c}\% \text { of } \\
\text { drugs }\end{array}$ & $\begin{array}{c}\text { Annual } \\
\text { expenditure (") }\end{array}$ & $\begin{array}{c}\% \text { of annual } \\
\text { expenditure }\end{array}$ \\
\hline I & 298 & 32.75 & 3.230 .443 & 82.55 \\
II & 446 & 49.01 & 612.936 & 15.66 \\
Total & 166 & 18.24 & 69.916 & 1.79 \\
\hline
\end{tabular}

Table 6. (ABC-VED) Matrix

\begin{tabular}{|c|c|c|c|c|c|c|}
\hline \multirow[b]{2}{*}{ Drugs Category } & \multicolumn{2}{|c|}{ V } & \multicolumn{2}{|c|}{$\mathrm{E}$} & \multicolumn{2}{|c|}{$\mathrm{D}$} \\
\hline & No. of drugs & $\begin{array}{c}\text { Annual } \\
\text { expenditure (") }\end{array}$ & No. of drugs & $\begin{array}{c}\text { Annual } \\
\text { expenditure (") }\end{array}$ & No. of drugs & $\begin{array}{c}\text { Annual } \\
\text { expenditure (") }\end{array}$ \\
\hline A & 13 & 1.250 .249 & 30 & 1.298 .178 & 3 & 193.914 \\
\hline B & 40 & 336.254 & 43 & 372.462 & 9 & 69.474 \\
\hline C & 212 & 151.847 & 394 & 171.001 & 166 & 69.915 \\
\hline
\end{tabular}


Table 8. Comparison of Research Results with Different (ABC), (VED) and (ABC-VED) Matrix Study Results

\begin{tabular}{|c|c|c|c|c|c|c|c|c|c|c|c|c|}
\hline \multirow[b]{2}{*}{ 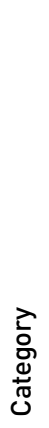 } & \multicolumn{2}{|c|}{$\begin{array}{l}\text { Present } \\
\text { Study }\end{array}$} & \multicolumn{2}{|c|}{$\begin{array}{c}\text { Vaz et al. } \\
\text { (2008) }\end{array}$} & \multicolumn{2}{|c|}{$\begin{array}{l}\text { Nigah et al. } \\
(2010)\end{array}$} & \multicolumn{2}{|c|}{$\begin{array}{c}\text { Khurana et al. } \\
\text { (2013) }\end{array}$} & \multicolumn{2}{|c|}{$\begin{array}{c}\text { Kumar et al. } \\
\text { (2015) }\end{array}$} & \multicolumn{2}{|c|}{$\begin{array}{l}\text { Pund et al. } \\
\text { (2016) }\end{array}$} \\
\hline & $\begin{array}{l}\text { ñ } \\
\text { on } \\
\frac{2}{0} \\
4 \\
0 \\
0\end{array}$ & $\begin{array}{l}0 \\
\frac{0}{3} \\
\frac{1}{0} \\
\frac{0}{0} \\
0 \\
\frac{0}{x} \\
0 \\
\frac{0}{0} \\
\frac{\pi}{2} \\
\frac{0}{0} \\
\frac{0}{0} \\
0\end{array}$ & $\begin{array}{l}\text { ñ } \\
\text { on } \\
\frac{1}{0} \\
4 \\
0 \\
0\end{array}$ & 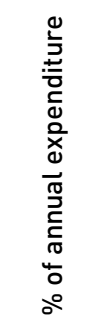 & 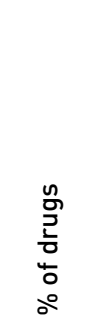 & 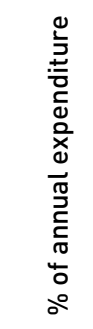 & 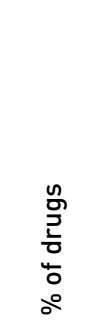 & 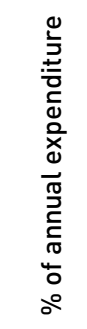 & 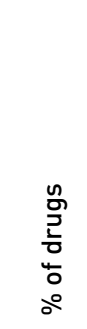 & 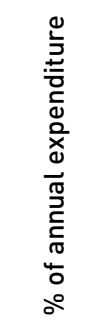 & \begin{tabular}{l} 
ñ \\
\multirow{2}{2}{} \\
$\frac{1}{0}$ \\
4 \\
0 \\
0 \\
0
\end{tabular} & 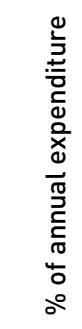 \\
\hline$A$ & 5.05 & 70.08 & 12.93 & 69.45 & 13.78 & 69.97 & 3.45 & 70.50 & 6.77 & 70.03 & 16.80 & 70.00 \\
\hline B & 10.11 & 19.88 & 19.54 & 20.48 & 21.85 & 19.95 & 6.90 & 19.68 & 19.27 & 19.98 & 21.80 & 20.10 \\
\hline C & 84.84 & 10.04 & 67.53 & 10.07 & 64.37 & 10.08 & 89.65 & 9.83 & 73.95 & 9.98 & 61.40 & 9.90 \\
\hline V & 29.12 & 44.42 & 12.36 & 15.67 & 12.11 & 17.14 & 32.41 & 70.90 & 13.14 & 19.00 & 35.30 & 34.30 \\
\hline$E$ & 51.32 & 47.06 & 47.12 & 70.02 & 59.38 & 72.38 & 61.38 & 28.72 & 56.37 & 68.00 & 50.40 & 49.50 \\
\hline D & 19.56 & 8.52 & 40.52 & 14.31 & 28.51 & 10.48 & 6.20 & 0.38 & 30.49 & 13.00 & 14.30 & 16.20 \\
\hline 1 & 32.75 & 82.55 & 22.99 & 74.80 & 22.09 & 74.21 & 33.80 & 92.33 & 21.00 & 69.45 & 47.90 & 82.30 \\
\hline II & 49.01 & 15.66 & 41.67 & 21.68 & 54.63 & 22.23 & 60.00 & 7.29 & 51.17 & 24.35 & 43.70 & 16.50 \\
\hline III & 18.24 & 1.79 & 35.34 & 3.52 & 23.28 & 3.56 & 6.20 & 0.38 & 27.83 & 6.20 & 8.40 & 1.20 \\
\hline
\end{tabular}

ing scarce financial resources to assets in the most appropriate manner. Therefore, in order to use resources efficiently, it is necessary to place a greater importance on the management of stocks, which is an important element in assets.

Investment mistakes in stocks will undermine the financial strength of the business and this may lead to the purchase of goods and services above market prices and to the interruption of the supply period. Moreover, the quality of the service provided and patient satisfaction will also lead to other problems which can cause significant damage. For this reason, inventory management plays a critical role in all health institutions and organizations, from medical centers to group hospitals.

Many methods are used for inventory management and it is possible to say that the (ABC-VED) matrix method will provide considerable benefits for hospitals because of the evaluations made both economically and in terms of vital importance. In view of the fact that they are simple and user-friendly, it is expected that these analyzes will be widely used by the managers.

According to the research results, it appears that this hospital mainly uses vital and expensive medicines. For this reason, it is crucial to determine the safety stock levels of the medicines considering the categories determined for each drug in this study. By this means, these analyzes will help managers to determine the safety stock level of medicines that constitute a significant portion of total expenditure and to effectively and efficiently manage scarce financial resources.

\section{Acknowledgements}

An earlier version of this paper was presented at the 1st International 11th Health and Hospital Administration Conference, 13-15 October, 2017, Trabzon, Turkey.
Conflict of Interest: The author have no conflict of interest to declare.

\section{REFERENCES}

- $\quad$ Agirbas I (2014). Saglik Kurumlarinda Finansal Yonetim ve Maliyet Analizi. Siyasal Kitabevi, Ankara.

- Devnani M, Gupta AK, Nigah R (2010). ABC and VED analysis of the pharmacy store of a tertiary care teaching, research and referral healthcare institute of India. J Young Pharmacists 2: 201205. [CrossRef]

- $\quad$ Electronic resource 1. (2017) Analysis of Aggregate Medicine Use Data, http://apps.who.int/medicinedocs/en/d/Js4882e/8.2.html. Accessed 07.01.2018.

- Gandhi P, Basur A (2000). Application of ABC analysis in medical store of ESIC, Delhi. Health Administrator 9\&10: 90-95.

- Gupta R, Gupta KK, Jain BR, Garg RK (2007). ABC and VED analysis in medical stores inventory control. Med J Armed Forces India 63 325-327. [CrossRef]

- Kant S, Pandaw CS, Nath LM (1996). A management technique for effective management of medical store in hospitals. Medical store management technique. J Acad Hosp Adm 8\&9: 4147.

- $\quad$ Khurana S, Chhillar N, Gautam VKS (2013). Inventory control techniques in medical stores of a tertiary care neuropsychiatry hospital in Delhi. Health 5: 8-13. [CrossRef]

- Kumar S, Chakravarty A (2015). ABC-VED analysis of expendable medical stores at a tertiary care hospital. Med J Armed Forces India 71: 24-27. [CrossRef]

- Madan AK, Ranganath MS (2014). Application of selective inventory control techniques for cutting tool inventory modeling and inventory reduction-A case study, International Conference of Advance Research and Innovation (ICARI), ISBN 978-93-5156328-0, 127-135.

- $\quad$ Nigah R, Devnani M, Gupta AK (2010). ABC and VED analysis of the pharmacy store of a tertiary care teaching, research and referral healthcare institute of India. J Young Pharmacists 2: 201205. [CrossRef] 
Istanbul J Pharm 48 (2): 43-48

- $\quad$ Pund SB, Kuril BM, Hashmi SJ, Doibale MK, Doifode SM (2016). ABCVED matrix analysis of Government Medical College Aurangabad drug store. Int J Community Med Public Health 3: 469-472. [CrossRef]

- Tengilimoglu D, Guzel A (2013). Hastanelerde Lojistik Yonetimi. In: Sur H, PaltekiT eds. Hastane Yonetimi, Nobel Matbaacilik, Istanbul, pp. 239-258.

- Vaz FS, Ferreira AM, Kulkarni MS, Motghare DD, Pereira-Antao I (2008). A study of drug expenditure at a tertiary care hospital: An ABC-VED analysis. J Health Manag 10: 119-127. [CrossRef]
- Wandalkar P, Pandit PT, Zite, AR (2013). ABC and VED analysis of the drug store of a tertiary care teaching hospital. Indian J Basic \& ApplMed Res 3: 126-131.

Yesilyurt O, Sulak H, Bayhan M (2015). Evaluation of Control Activities of Inventory Management with Analysis of ABC and VED in Health Sector: Instance of Isparta State Hospital. Suleyman Demirel University Journal of Faculty of Economics \& Administrative Sciences 20: 365-376. 